\title{
ARCHITECTURE 'TALKS BACK': ON THE (IM)POSSIBILITIES OF DESIGNING A CRITICAL ARCHITECTURAL PROJECT
}

\begin{abstract}
A B S T R A C T
Claims on critical positions in architecture are common ground in contemporary practice and reflection. This article probes into the critical capacity of the architectural project by returning to the notion of 'typological criticism' that Manfredo Tafuri introduced, as well as to the concept of the 'semi-autonomy' of architecture as theoretized by Louis Althusser. The article argues that the criticality of the architectural project resides in its mediation between autonomous and heteronomous aspects and proceeds through the entity of the architectural type.
\end{abstract}


'Talking back' is not usually termed as a quality of architecture. It belongs to the realm of upbringing and refers to the moment where the child reaches a degree of autonomy that allows for a radical response to the statements of its parents. The child finds itself in a state of disagreement with the parental viewpoints and thus utters counter-arguments. This reaction is generally described as 'talking back' and is from the adults perspective alternatively considered as an occurrence of inappropriate behavior or as an instance of emancipation, but always as a 'critical' moment in the parent-child relation.

Critical positions in architectural culture have been widely studied over the last years. A broad series of conferences, publications and theme issues of journals have been devoted to the mutual relations between critical and architectural practices. ${ }^{1}$ In addition, architects relentlessly claim that they develop critical approaches, concepts and instruments - and thereby play an avant-garde role. Notions as 'critical design' and 'critical architecture' have become popular within contemporary architectural discourse, claiming an important societal role for architects and urban designers. Simultaneously another debate has emerged. In North-America, but also in Europe, people have started to argue that we have entered a post-critical era. Essays like 'Notes around the Doppler Effect and Other Moods of Modernism' by Sarah Whiting and Robert Somol have engendered an entire school of architects and theorists that maintain that criticality promotes an architecture of stunted creativity and retrogression. ${ }^{2}$ Instead, the post-critics suggest that architecture should leave its ambition to be critical and rather investigate intelligence, projection, innovation and provision.

The positions seem to be contradictory. Hence, questions emerge as: What about the possibility for constructing a critical architectural project? Is the notion of 'critical architecture' a sheer rhetorical figure that has to cover the architects reduced role within a society that is increasingly defined by the movement of capital and labor? Does it represent the last convulsions of a discipline that is about to loose all of its impact? Or is there more at hand and can there be something as a genuinely critical architectural project within our contemporary condition?

TYPOLOGICAL CRITICISM:

ON THE POSSIBILITY OF CRITIQUE BY DESIGN

To start answering some of these questions on the critical capacity of contemporary architectural design, it is worthwhile to return to the notion of 'typological criticism' that the Italian critic Manfredo Tafuri introduced 
in his book Teoria e storia dell'architettura in $1968 .^{3}$ Tafuri refers to a particular approach of 'criticism by design' that he discerns most clearly in the architectural culture of the 1960s. He recognizes 'typological criticism' in such a diverse projects as Alison and Peter Smithson's Golden Lane Project (1952), Giancarlo De Carlo's Masterplan for Urbino (1958-1964) and Carlo Aymonimo and Aldo Rossi's proposal for the Gallaratese neighborhood (1967). But also the investigations of the relation between urban structure and infrastructures in the Centro Direzionale by Aldo Rossi, Vittorio Gregotti and Guido Canella, the Tokyo Bay Masterplan by Kenzo Tange and the City Center of Cumbernauld New Town by Geoffrey Copcutt are considered as instances of typological criticism.

Tafuri coins this broad spectrum of design approaches 'criticism' because they all represent a clear position vis-à-vis the body of architectural knowledge that has been established throughout history. Instead of regarding architectural design as an invention 'ex nihilo', these different architects depart from an indepth understanding of the stock of historical solutions in order to define new models, systems and approaches. Hence, Tafuri claims that architects as Alison and Peter Smithson, Giancarlo de Carlo and Carlo Aymonino - in spite of large theoretical and stylistic differences - share that they base their architectural an urban attitudes on a firm comprehension of modern masters such as Bruno Taut, August Klein and Ludwig Hilberseimer. To be more precise, he claims that these architects develop their contemporary positions as a critique of the body of know-how that the modern movement in architecture has brought to the fore during the 1920s and 1930s. Remarkable it is that this critique is not formulated by means of a critical essay, cartoon or collage, but rather through the very design of an architectural project.

Tafuri points out that an architectural project can maintain such a critical relation to the recent past, because design thinking proceeds by means of a very characteristic entity: typology. For Tafuri all architectural design encompasses the definition of spatial, material and functional articulations and thus articulates a particular type. Moreover, he argues that the use of a particular architectural type has the capacity to relate to historical approaches, but simultaneously - because of its transformative properties - can be redefined to respond to contemporary problems. An architectural type can play a role on various scale levels and can be re-interpreted from different angles: "Its size can be reduced to the study of a single object, and immediately afterwards can stretch out to consider that very same object in its urban thematic; or it can touch on brand new themes, formulated on a pure experimental basis." 
Hence, Tafuri claims that with the adaptation of the architectural type not only a concrete assignment is addressed, but also a criticism is uttered towards the existing body of architectural knowledge on this particular type. In addition, the confrontation of a particular type with a specific program or a particular context can result in symbiosis, contradiction or ambiguity -and thus install a critical relation.

Tafuri claims that it is characteristic for 'typological criticism' that projects reach beyond 'solution finding' for a program, context or situation, while at the same time relying strongly on concrete conditions and situations. Hence, when Alison and Peter Smithson propose an innovative hybrid urban structure for the Mehringplatz in Berlin (1962), they go beyond a simple response to available data and requirements, while proposing a true and genuine architectural project for the city center of Berlin: "Realism in the choice of the samples, and unprejudiced experimentalism in the formulation of the new models." Indeed, this complex combination of formulating new approaches for a real urban situation, while relying on the stock of knowledge that is available in architectural history, seems to be characteristic for typological criticism. It is what binds the Smithsons' project for Berlin Mehringplatz to the projects of Gregotti and Rossi for Centro Direzionale in Italy. They both start from approaches and configurations that are well-known to examine the innovative problem of new city centers. They go beyond a simple response to available data and requirements, while remaining on this side of true and genuine architectural proposals.

Typological criticism can be said to open two alleys of criticism. On the one hand it is concerned with the potential of particular architectural approaches: it evaluates the performance of particular complex or simple typologies, of specific multivalent or mono-valent compositions, of distinct systems that are open or closed to time and space. Typological criticism evaluates the functioning of these architectural types, models and approaches by inserting them in particular conditions and contexts. On the other hand, typological criticism critically investigates the urban situation that is encountered. Projects question the urban situation in which they intervene, they evaluate its potential to accommodate certain uses or to play a certain role within the wider urban territory. Hence, Tafuri points out that this type of criticism is essentially urban in its character. It emerges from its interaction with existing and real urban situations. However, this urban criticism does not affect the city as a whole, but rather approaches the city in piecemeal ways through the scale level of the architectural project. 
Tafuri's main point is that 'typological criticism' proceeds through a very particular mode: architectural design. He proposes a criticism that starts from the material, formal and spatial articulation of 'an architectural project' and develops a critical perspective from there: "the critical stream we are dealing with takes reality as its starting point and models on it a reading immediately translated into systems that modifying its single components, or, in extreme cases, its fundamental laws." ${ }^{\prime 6}$ Indeed, Tafuri points to the quality of an architectural project to deconstruct, scrutinize and reassemble urban elements and qualities that are thought of as immutable and undisputable. As such, architectural design has the capacity to confront so-called 'normal' or 'obvious' systems with alternative configurations, forms and images - thereby placing present architectural solutions in a critical perspective. In addition, an architectural project has also the capacity to illustrate the potential of future urban situations - not in abstract terms, but through the proposal of concrete models and typologies and the demonstration of their possible roles in actual urban situations. In typological criticism: "historical analysis, critical examination, critical function of the image and demonstrative value of planning, are all indissolubly connected."’

Good examples of 'typological criticism', according to Tafuri, can be found in the large array of projects that during the 1960s deal with the so-called 'architecture of the territory'. Increasing automotive traffic and explosive urban development radically changed the condition in which architects worked in the 1960s. If before the historical city had been the matrix in which architects operated, then in the 1950s and 1960s the territory became the new scale of reference. Paradoxically, this scale of the territory - within the Italian discourse coined città territorio - and especially its infrastructures (such as bus stations, parking garages and road infrastructures) became gradually more removed from the realm of architecture and increasingly the domain of engineers. As a reaction against this development a wide variety of architects started to define critical architectural projects within this context. A prime example is the competition for the so-called Centro Direzionale of Torino in 1963 in which Aldo Rossi participated. The Centro Direzionale was the figure par excellence of a new urbanity. All over Italy these new office complexes with related car infrastructure arose along highways as the urban centers of the future. In their so-called Locomotivo project Rossi and his partners illustrate that it is possible to think the Centro Direzionale as more then a sheer car and office infrastructure. By using a simple 'courtyard typology' they propose a project that - in one single figure - accommodates the different infrastructures, defines a large and newfangled public figure within the città territorio and offers a clear urban image to the Centro Direzionale. 
A same sort of attitude Tafuri discovers in the studies of Geoffrey Copcutt for the centre of the New Town Cumbernauld near Glasgow (1959-1967). This project can be looked upon as an attempt to define a new urban system in which pedestrians and cars would cohabit in an integrated fashion. Cumbernauld alludes to some of the forms and types that were proposed by modern architects, but also makes reference to more ordinary infrastructures of car parks and traffic junctions. These different references, from within and without the realm of architecture, are brought together in a newfangled urban figure that opens a fresh perspective on the character of a contemporary town centre within the wider territory. This is a particular characteristic of 'typological criticism': it does not unfold its critique from an ideological framework or an abstract set of values, but rather from a concrete architectural intervention that resonates simultaneously with the history of architecture and with a particular urban condition.

\section{THE SEMI-AUTONOMY OF ARCHITECTURE}

In order to grasp the span of Tafuri's concept of typological criticism - a criticism that is based both on reference to the history of architecture and to the external urban conditions - it is useful to recall the perspective on architecture that the French thinker Louis Althusser brought to the fore in his well-known essay 'Ideology and Ideological State Apparatuses (Notes towards an Investigation) '. ${ }^{8}$ In this essay Althusser introduces the concept of "relative autonomy" or "semi-autonomy" to illuminate the relationship that the cultural realm (including architecture) maintains with the economical, political and social realms. Semi-autonomy signifies that none of these realms coincides with the others, or is completely independent of the others. In other words, architecture is not the sheer expression of the social, political and economical matrix from which it emerges, but is certainly not also disconnected from it. Conversely, architecture develops according to its internal and autonomous laws and logics, but is never fully disconnected from the heteronomous set of conditions from which it came into being. This makes Althusser conclude that architecture is "semi-autonomous".

Althusser's viewpoint challenges well-established concepts in architectural discourse and practice. It undermines the belief that architecture can be the ultimate expression of a certain 'zeitgeist' or even a particular social program or function - viewpoints that strongly colored the thinking of the architects of the modern movement. Since architecture never fully coincides with the social, political and economic matrix of its time, it cannot be its full and perfect expression. At the same time Althusser's viewpoint destabilizes every claim 
for a fully autonomous architecture, made by neo-rationalist architects such as Aldo Rossi or Giorgio Grassi. Indeed, if architectural practice maintains a relation with other practices and realms, it is itself the expression of these resonances. Hence architecture seems to be simultaneously autonomous and heteronomous. Autonomous, because it develops according to typological, structural and material logics that belong exclusively to the field of architecture and its history. Heteronomous, because architecture is the formal, material and spatial expression of economic, social and political conditions, norms and constellations.

Althusser thus argues that architecture is always part of a complex formation with other semi-autonomous practices. Hence architectural practice exists as part of a system of interrelated artistic, economic, political, cultural and ideological practices; a formation characterized by relations of domination and subordination. Moreover, he suggests that within a formation there is a "structural causality" between a practice as architecture and other economic, political and ideological practices. They are structurally related and thus depend upon one another; architecture depends on economic, social and political conditions and vice-versa, economic and social practices need spatial conditions to unfold. At the same time, however, Althusser also insists on the "relative autonomy" of the different practices. Hence, architectural practice develops according to different logics and rationales than social and political practices. Each of them, Althusser argues, has its proper rhythms of development internal to itself such that the formation is always "unevenly developed," always a complex constellation of multiple contradictions.

With his depiction of the field of tension between structural causality and relative autonomy Althusser touches upon one of the most important characteristics of architecture. After all, it is exactly this property to be simultaneously related to a heteronomous field of ideological, economic, political and social practices, as well as to the autonomous domain of aesthetic, structural and functional logics, that endows architecture with a critical capacity. The encounter between autonomous and heteronomous aspects of architecture engenders uncertainty, dissonance and contradiction - and thereby opens a field for critical reflection. Indeed, architecture depends on the political and economical constraints that allow building projects to emerge, but that it has simultaneously - and thanks to its autonomous qualities - the capacity to neglect, question or even contradict these. In this moment between autonomy and heteronomy the critical capacity of architecture emerges; at this instance architecture 'talks back' to its own history, but also to the economic, social and political condition that it interferes with. 
The well-known project for the Golden Lane by Alison and Peter Smithson is a good case study to illustrate this critical capacity. This project for a housing estate on a bombed neighborhood of London is a clear criticism of the modern typologies for larger housing blocks that were developed during the post-war period, most notably Le Corbusiers Unité d'Habitation. The Smithsons criticize the Unite typology in several ways. They position their 'streets in the air' on the perimeter of the building and thus connect them visually to the larger public urban landscape. In such a way they comment the internalized position of the 'Rue Interieur' in Le Corbusiers typology that deprived every connection to the surrounding city. In addition, the Smithsons introduce a threshold between street and dwelling in the form of a little logia, pointing to the abrupt transition between public street and private dwelling in Le Corbusier's approach. And finally, they also propose connections between the different 'streets in the air' into a new urban system of 'clusters'. Thereby they criticize the isolation and disconnection of the interior streets in the original Unité. In other words, the Smithsons use their project for the Golden Lane in order to transform the Unite and thereby offer a sharp criticism of one of the most canonic architectural typologies of recent architectural history.

However, the Golden Lane project was not only a comment on the 'autonomous' developments in recent architectural history, but also of the 'heteronomous' political, economical and social characteristics of the urban condition of London. Indeed, the Smithsons proposal for the Golden Lane can be seen as a comment on the existing structure of London that consisted of clear socio-spatial distinctions between different neighborhoods. The Smithsons literally juxtapose their clusters of 'internal streets' on the existing structure of the city. On top of the present urban tissue and public spaces a new system of interrelated 'streets in the air' is projected. The Smithsons believed that this combination of old and new urban tissue would engender a new spatial system that in its turn would accommodate new forms of collectivity and public domains. These would offer the possibility to encounter, even in the most popular neighborhoods, as well close neighbors as the cosmopolitan inhabitants of London. Hence, they visualize in their collages streets in the air that are populated by playing kids, but also by Joe DiMaggio and Marilyn Monroe. They are all part of a new collectivity; they all participate in a new urban realm. Out of this perspective, the Golden Lane appears as project that is critical of the class-structure that was still present in London of the 1950s. The Golden Lane 'talks back' as well to the field of architecture, as to its urban condition. It is in the relation between both that the project gets its full critical capacity. 


\section{ARCHITECTURE 'TALKS BACK': CRITICAL PRACTICES}

This ability to 'talk back', this critical capacity of the architectural project, is not something which is reserved to projects of the 1950s and 1960s. Quite on the contrary, also in current practice and thinking this capacity can play a paramount role. After all, the complexity of contemporary architectural practice, as well as the large number of actors, claims and uses that are involved, call for architectural projects that surpass mere "utilitarian problemsolving" or "surface-styling" to fulfill other, more committed roles.

A first critical role that the architectural project can play relates to the large variety of social, cultural, political and economic logics that guide our present urban condition. Architecture's relative autonomy (and thus distance) vis-àvis these heteronomous drivers of our present urban condition allows it to play an elucidating and exploratory role. By making formal, material and spatial claims in the form of an architectural project, designers touch upon a wide variety of heteronomous parameters in the social, cultural, economical and political fields. Hence, an architectural project - though being formulated in sheer architectural terms - can be looked upon as a hypothesis on complex social and economic matters. It is out of this perspective that architectural projects have the ability to illuminate the complexity of our present urban condition. They can articulate - and thus concretize - the encounter between different rationales. In addition, they have the power to not just elucidate actual end products, but also to focus on opportunities, scenarios and possibilities of bringing these diverse logics and intentions together. Thanks to its imaginative power, architectural design can put various spatial claims and programs side by side. As such it can illuminate problems, but also define future projects and visualize possible developments. Architectural projects can 'talk back' to the various social, cultural, political and economic logics that steer our present urban condition. There is an increasing need for architectural projects that are defined as a means of testing something: logics, drivers, perceptions and intentions.

A second critical role relates to the variety of actors and spatial claims that are characteristic for our present urban condition. Here, too, the starting point is design's imaginative power - or to say it differently, the characteristic that architecture combines autonomous and heteronomous considerations. An enumeration of the wishes of different actors often results in the formulation of a list of demands that is unfeasible within a certain space, time and constraints. An innovative architectural design can confront these demands with one another (for example by mixing generic and specific 
spaces), combine them within a single space (a private outdoor space within a public indoor space) or superimpose them (a public outdoor space above a public indoor space). To say it differently, since the autonomy of architecture is relative, architectural projects can be considered and commented by professionals from other fields. This makes an architectural project the best possible medium for uniting different actors with divergent spatial claims. Design's imaginative power - its capacity to integrate heteronomous claims in innovative autonomous form - gives the different claims a concrete spatial expression. It stimulates debate about space as well as the exploration of concrete spatial solutions with which different actors can agree. Out of this perspective architectural design can play a critical role as a vehicle for negotiation, conflict management and co-production.

A third critical role that the architectural project can play, relates to its own history. Indeed, architectural projects have the ability to comment on the development of the discipline: they can amend existing approaches, systems and typologies. As such, architecture can 'speak back' to its own recent past. However, this capacity seems to be suspiciously absent in contemporary architectural culture that remains to be haunted with the desire for the new. In contradistinction with the typological criticism of the Smithsons, Rossi and Copcutt - based on a revision of systems and typologies of the modern movement - contemporary architectural practice shows a limited interest in criticizing existing approaches. Yesterday's design projects are fully denounced not so much because their flaws have amply been demonstrated, nor because their hypotheses have proved to be false, but simply because they lost appeal due to the fact that a newer and more attractive rival appeared on the scene. This particular feature prevents contemporary architectural culture of accumulating a certain body of critical knowledge on how architectural projects are conceived, how they are realized and how they perform within reality. Tafuri's notion of typological criticism shows an alternative path: It suggest to think of the criticality of an architectural project not as overthrowing the existing, but rather as a particular engagement with the recent past.

It is clear that the field of tension between autonomous and heteronomous aspects, which is so particular for architectural design offers a rich field of possibilities for the development of critical stances. It offers architecture the ability 'to talk back' from various angles. It is remarkable that this critical role does no longer depend on a predetermined set of values, nor on a larger ideological frame, but is strongly related to architecture's capacity to engage in concrete terms with the reality of a particular urban condition while remaining 
connected to the conceptual sphere of its own history. In this moment of simultaneous connection to heteronomous and autonomous aspects resides the critical capacity of architecture. It is from there that an architectural project can criticize both its own history and the social, cultural, economic and political condition in which it intervenes. However, and as a conclusion, it remains important to notice that architecture's semi-autonomy implies that it can never fully interact with - or even less entirely transform or contradict - economical, cultural social or political practices. More precisely, architecture is partially dependent on them. It is there that the paradox of a critical architecture resides: its 'talking back' is always partial and conditional. 2010; Agnès Deboulet et.al. (ed.), La critique architecturale. Questions - frontières - desseins, Editions de la Villette, Paris, 2008; Kenneth Frampton \& Hélène Jannière (ed.), «La critique en temps et lieux», themed issue Cahiers de la recherche architecturale et urbaine, nrs. 24/25, 2009; Hilde Heynen, Jean-Louis Genard (ed.), Critical Tools, La Lettre Volée, Brussels, forthcomming; Rendell, Jane et. all. (ed.), Critical Architecture, Routledge, London, 2007 Perspecta 33 (2002): 72-77. the English translation Manfredo Tafuri, Theories and History of Architecture (Granada: London, 1980), 158-163. 
Louis Althusser, Ideologie et appareils idéologiques d'État (notes pour une recherche) La Pensée 151 (1970): 3-38; tr. as "Ideology and Ideological State Apparatuses: Notes Towards an Investigation" by Ben Brewster in Lenin and Philosophy and Other Essays, Monthly Review, New York, 2002.

Althusser, Louis, Ideologie et appareils idéologiques d'État (notes pour une recherche) La Pensée 151 (1970): 3-38; tr. as "Ideology and Ideological State Apparatuses: Notes Towards an Investigation" by Ben Brewster in Lenin and Philosophy and Other Essays, Monthly Review, New York, 2002.

'Constructing Criticism', OASE. Architectural Journal, no. 82, 2010.

Deboulet, Agnes, et.al. (ed.), La critique architecturale. Questions - frontières - desseins, Editions de la Villette, Paris, 2008.

Frampton, Keneth, Jannière, Hélène (ed.), «La critique en temps et lieux», themed issue Cahiers de la recherche architecturale et urbaine, 24/25, 2009.

Heynen, Hilde, Genard, Jean-Louis (ed.), Critical Tools, La Lettre Volée, Brussels, 2009.

Rendell, Jane et. all. (ed.), Critical Architecture, Routledge, London, 2007.

Somol, Robert, Whiting, Sarah, "Notes around the Doppler Effect and Other Moods of Modernism". Perspecta 33 (2002): 72-77.

Tafuri, Manfredo, Teoria e storia dell'architettura. Bari, Laterza, 1968. All quotes are taken from the English translation Manfredo Tafuri. Theories and History of Architecture, Granada, London, 1980, 158-163. 